\title{
Identidade e tecnologia social: um estudo junto às artesãs da Vila Rural Esperança
}

\author{
Identity and social technology: a study on the craftsmen of Esperança Rural Village
}

\author{
Maíra Coelho Bonilha ${ }^{1}$ \\ Maria Iolanda Sachuk ${ }^{2}$
}

\section{Resumo}

Tanto o mundo quanto as pessoas estão num contínuo processo de transformação, construção e constituição, no qual o sujeito e o ambiente afetam-se mutuamente por meio das múltiplas relações estabelecidas. Sendo assim, o objetivo no presente artigo foi o de compreender de que forma a tecnologia social contribuiu para o processo de construção e constituição da identidade das artesãs da comunidade da Vila Rural Esperança, a partir do momento em que tal tecnologia transformadora (social e humana) inseriu-se em seu ambiente e foi incorporada no decorrer do projeto Seda Justa. Além de tratar-se de tema atual, como a tecnologia social e a identidade, suscita um diálogo interdisciplinar. Sabe-se que todo e qualquer tipo de transformação e forma de empreendimento/organização imprime marcas significativas nas relações profissionais e pessoais, acerca do trabalho, o que merece estudos aprofundados. A identidade sempre é afetada pelas significações culturais e varia de acordo com as situações vivenciadas e a história de vida dos sujeitos. Em virtude disso, escolheu-se o método da história de vida para a coleta dos dados, e a hermenêutica como base de interpretação. Dessa forma, a pesquisa permitiu, por meio dos relatos e das memórias das participantes da pesquisa, a exteriorização de suas experiências e sentimentos: o que valorizam, pensam, sentem e fazem, revelando, assim, o processo de construção de suas identidades e seus elementos constituintes.

Palavras-chave: tecnologia social; identidade; unidade; fragmentação; transformação.

\begin{abstract}
The world and its people are in a state of continuous transformation, construction and constitution by which the agent and the environment reciprocally affect one another through several established roles. This essay investigates the way in which social technology contributes to the process of construction and constitution of the Esperança Rural Village craftsmen's identity by their insertion of transformation technology (both social and human) in their milieu and its incorporation during the execution of the Seda Justa project. The themes, such as social technology and identity, are currently debated and give rise to an interdisciplinary dialogue. All types of transformation and form of entrepreneurship/organization leave their significant marks on professional and personal relationships with regard to labor. Consequently, this fact requires further studies and research. Identity is always affected by cultural meanings and
\end{abstract}

Artigo submetido em abril de 2010 e aceito para publicação em fevereiro de 2011.

1 Mestre em Administração pelo PPA - UEL/UEM - Universidade Estadual de Maringá; Funcionária da Caixa Econômica Federal. Endereço: Rua Osvaldo Cruz, 317, Ap. 301, Zona 07, CEP 87020-200, Maringá, PR, Brasil. E-mail: mabonilha@hotmail.com

2 Professora Doutora em Administração pela FGV/EAESP; Professora Associada do Curso de Administração da UEM - Universidade Estadual de Maringá. Endereço: Av. Colombo, 5790, Jardim Universitário - DAD, CEP 87020-900, Maringá, PR, Brasil. E-mail: mariaiolanda.sachuk@gmail.com 
varies according to the situation that is experienced and the history of the subjects' lives. The method of life history for data collection and hermeneutics as an interpretation basis were chosen. Through the participants' reports and memories, this study produced the exteriorization of their experiences and feelings: what they value, what they think, feel and do, and thus the construction process of their identities and their constitutive elements.

Keywords: social technology; identity; unity; fragmentation; transformation.

\section{Introdução}

O mundo atual é dinâmico, as mudanças ocorrem com tamanha velocidade que as pessoas são levadas a se adaptar a todo momento. Assim, foi de extrema relevância compreender de que forma a tecnologia social contribuiu para o processo de construção e constituição da identidade das artesãs da comunidade da Vila Rural Esperança quando da inserção desta tecnologia em seu ambiente e a sua incorporação por elas, o que foi possível por meio do resgate de suas histórias de vida. Em virtude de as histórias pessoais possuírem diversas situações particulares, que, ao final, constroem e constituem a identidade das pessoas, pôde-se perceber o que elas valorizam, pensam, sentem e fazem.

Alguns elementos da identidade tendem a permanecer devido a valores e crenças interiorizados, ainda que outros elementos sejam aceitos e alterados. No entanto, a incorporação de elementos na identidade herdada e na identidade adquirida no contexto social proporciona mudanças constantes de alguns elementos ao longo da vida das pessoas. Por isso há a construção, manutenção ou desconstrução da identidade.

As construções e constituições identitárias podem ser abordadas de diferentes perspectivas de interpretação, as quais podem ser filosófica, psicológica, social ou psicossocial. Ressalta-se, no entanto, que este trabalho não se restringe a nenhuma perspectiva de interpretação e que não privilegia nenhuma abordagem epistemológica específica.

Para este trabalho, foi realizada uma compilação de diversas obras a respeito do tema identidade. Buscou-se uma integração entre vários autores, a fim de formar uma concepção mais abrangente, que pudesse buscar a construção e a constituição individual ou pessoal do conceito de si mesmo, de uma forma não simplista, por meio da história de vida particular de cada artesã em seu respectivo contexto.

O sustento da maioria das artesãs da comunidade da Vila Rural Esperança dependia exclusivamente da criação do bicho-da-seda. Até que o atual consultor dos Produtores Rurais da comunidade da Vila Rural Esperança sugeriu o aproveitamento dos fios do bicho-da-seda aos moradores da comunidade. Assim, surgiu o projeto denominado Seda Justa, com a participação das artesãs da comunidade da Vila Rural Esperança, no início de 2007, por intermédio da EMATER-PR (Empresa de Assistência Técnica e Extensão Rural). O projeto tornou-se viável com a adesão de algumas moradoras, visto que já detinham o conhecimento/técnica do tricô; o que possibilitou, posteriormente, o repasse desse conhecimento para as demais artesãs.

A ideia do projeto Seda Justa é proporcionar, por meio de parceiros, uma alternativa de renda, remunerar de forma justa e digna as pequenas artesãs para que melhorem sua condição de vida. O projeto adota o conceito de comércio justo e faz uso da tecnologia social que se transformou numa política pública a partir do mês de julho de 2009, mudando, também, neste período, a sua forma de organização de associação para cooperativa, recebendo o nome de Artisans Brasil - Seda Justa - COPRASEDA (Cooperativa dos Produtores Rurais de Artesanato em Seda).

Por meio dessa transformação, será possível englobar um número maior de participantes, acarretando aumento de produção e expansão de negócios em países que demandem por produtos artesanais dentro do conceito de comércio justo. Atualmente, o projeto Seda Justa atende somente ao mercado externo, mais precisamente algumas lojas da rede francesa Artisans du Monde. 
As artesãs da comunidade da Vila Rural Esperança confeccionam cachecóis com fios do bicho-da-seda, que é cultivado por algumas delas e pela comunidade na própria Vila Rural Esperança, que foi construída no ano de 2000 e está localizada na cidade de Nova Esperança, no Estado do Paraná. Atualmente, 78 das 127 famílias que lá residem se dedicam à criação de bicho-da-seda que lhes proporciona uma alternativa de renda. Desta forma, as próprias artesãs estão conseguindo transformar a sua própria realidade, por meio da articulação coletiva e incorporação da tecnologia social.

A tecnologia social é um instrumento desenvolvido para solucionar problemas nesse âmbito e utilizado como transformador de pessoas. Possibilita que indivíduos excluídos sejam ressocializados e formem (construam e constituam) ou transformem a sua própria identidade por meio da apropriação dessa tecnologia que engloba o conhecimento técnico-científico e os benefícios gerados pela Ciência, Tecnologia e Inovação (CT\&I). Os programas de tecnologia social contam com o apoio e incentivo governamentais para a sua inclusão, implantação e seu desenvolvimento nas políticas públicas.

Diante do exposto, o seguinte problema de pesquisa foi elaborado: "A tecnologia social contribuiu para o processo de construção e constituição da identidade das artesãs da comunidade da Vila Rural Esperança?"

\section{Tecnologia social (TS)}

No Brasil, de acordo com Bilancieri e Padoveze (2006), desde 1970 as políticas públicas direcionadas ao mercado de trabalho vêm sendo criadas e desenvolvidas como uma forma de compensar a redução do número de postos de trabalho à disposição da população. Entre as políticas públicas de apoio ao desenvolvimento local estão as que incentivam o desenvolvimento de tecnologias sociais.

Segundo Dagnino (2008), o conceito de tecnologia social é novo, "revolucionário" (transformador social) e será cada vez mais incorporado às políticas públicas, às ações de governo, ao mercado e ao meio acadêmico. De acordo com esse autor, essa tecnologia visa promover a inclusão social e surgiu para contestar a tecnologia convencional, que causou altos índices de desemprego.

Dagnino et al. (2004) defendem a ideia de que esse tipo de tecnologia é capaz de evitar os prejuízos sociais e ambientais decorridos da adoção das tecnologias convencionais e, com isso, diminuir a dependência dos países periféricos em relação aos fornecedores usuais de tecnologia. Mas para isso, segundo eles, há a necessidade da participação do governo e da população na implementação de políticas de incentivo ao uso desse novo modelo.

De acordo com Rutkowski e Lianza (2004), este novo modelo de desenvolvimento econômico, não predatório, postula o uso racional dos recursos naturais, visto que estes são esgotáveis, como forma de melhorar a qualidade de vida dos habitantes. Busca-se o desenvolvimento sustentável como forma de equilíbrio entre o desenvolvimento e a preservação dos recursos naturais.

Segundo a Rede de Tecnologia Social (RTS, 2008), a promoção da tecnologia social resulta de políticas públicas, é financiada com recursos públicos e tem como função suprir as necessidades da população, priorizando as dimensões humana e social. Ela pode ser entendida como produtos, técnicas e/ou metodologias reaplicáveis, desenvolvidas na interação com a comunidade e que representem efetivas soluções de transformação social. Essa tecnologia é expressa pela intervenção social, que é inclusiva em todos os seus momentos, desenvolvida e difundida de acordo com as possibilidades e as limitações de cada comunidade ou local. É uma proposta participativa de construção do conhecimento, de fazer ciência e tecnologia para o desenvolvimento e realização do ser humano e de seus interesses coletivos, ou seja, é uma forma de reduzir as desigualdades sociais. 
Para Lassance Júnior e Pedreira (2004), os procedimentos e métodos das tecnologias sociais cumprem pelo menos quatro fases essenciais que fazem parte do segredo de sua viabilidade em escala: de criação, uma vez que as tecnologias sociais nascem ou da sabedoria popular, ou do conhecimento científico, ou da combinação de ambas (especialistas); de viabilidade técnica, na qual há a consolidação de um padrão tecnológico; de viabilidade política (governos e administração - parte burocrática); e de viabilidade social (entidades civis e outras organizações devem reivindicar seu uso e apontá-la como solução). Tal respaldo é de suma importância para garantir a sobrevivência do projeto. Ou seja, a tecnologia precisa ter bases de apoio para que seja demonstrada, reaplicada e bem orientada a quem a aplica, garantindo dessa forma a sua eficácia. Esses circuitos de relações estabelecerão a sua inclusão ou exclusão no horizonte das políticas públicas. No entanto, apesar de existirem todos esses circuitos, ainda assim o empreendimento pode não lograr êxito. Tudo dependerá da forma de atuação e gestão frente às situações e negócios.

Em geral, a tecnologia social possui apenas dimensão local, aplica-se a pessoas, famílias, cooperativas e associações. No entanto, há tentativas de mudar esse cenário para que as tecnologias sociais ganhem maiores proporções em âmbito nacional, junto ao governo e à sociedade, e passem a ser visualizadas como um projeto nacional. Consequentemente maiores incentivos e apoios poderão ser fornecidos para a implantação e reaplicação destas tecnologias (DAGNINO, 2008).

Por isso, de acordo com a Rede de Tecnologia Social (RTS, 2008), a comunidade deve participar do processo de formulação, implantação e reaplicação de uma tecnologia, para que esta atenda a sua realidade e assim possa gerar a transformação social pretendida. As tecnologias não são copiadas - o termo não é replicar, mas sim reaplicar, o que implica adaptar de forma criativa o que já existe em um lugar para outros lugares.

Desse modo, a implementação de tecnologias sociais requer o registro das experiências obtidas num histórico, com o detalhamento dos pormenores da metodologia utilizada, para facilitar a reaplicação em outros lugares (OTERO e JARDIM, 2004).

Segundo Mariga (2004), a busca por conhecimentos técnico-científicos compete aos próprios interessados; assim se tornam sujeitos-ativos da própria história, não apenas a contemplando ou descrevendo. Isso se dá por intermédio de suas ações e avaliações sobre a realidade, o que implica a busca por novos conhecimentos que os capacitem a uma atuação mais crítica, consciente, confiante e independente, bem como uma prática integral da cidadania.

Assim, há todo um movimento direcionado à emancipação dos atores envolvidos, levando os próprios produtores e usuários das tecnologias sociais a se apropriar de inovações gerenciais já disseminadas pelas organizações e a construir soluções que venham a beneficiá-los. Há também o interesse em definir certificações participativas para assegurar condições legítimas de reaplicabilidade (efeito multiplicador) da tecnologia social (NEDER, 2008).

Dessa forma, segundo a Rede de Tecnologia Social, a proposta é desenvolver e disseminar uma tecnologia que seja

[...] adaptada a pequenos produtores e consumidores de baixo poder econômico; não promovedora do controle, segmentação, hierarquização e dominação nas relações patrãoempregado; orientada para o mercado interno de massa; incentivadora do potencial e da criatividade do produtor direto e dos usuários; capaz de viabilizar economicamente os empreendimentos como cooperativas populares, incubadoras e pequenas empresas. (RTS, 2006, p. 19).

O homem, por meio da incorporação da tecnologia social e da execução dessa atividade, irá transformar a si mesmo e a realidade que o circunda simultaneamente, o que provocará modificações em sua identidade. A 
seguir, serão apresentados a concepção de identidade individual ou pessoal, sua construção e os elementos que a constituem, dando ênfase a alguns deles.

\section{Construção da identidade}

O processo de construção da identidade é complexo e, muitas vezes, doloroso, pois a pessoa está sempre em busca do conhecer-se e reciclar-se por meio das vivências pessoais (criação e manutenção da identidade). Embora a pessoa espere ter uma identidade permanente, sabe que ela é apenas temporária (PEREIRA; TEIXEIRA; OJIMA, 2005).

Segundo Bauman (2005), o processo de construção da identidade pessoal não é algo que já existe a priori; ele se dá a partir de escolhas e alternativas da própria pessoa ao longo do seu percurso. Dessa forma, tanto a identidade como o pertencimento não são sólidos e nem garantidos por toda a vida; pelo contrário, são bastante negociáveis e revogáveis. São afazeres a serem realizados por meio de decisões, dos caminhos percorridos, do modo de agir e da determinação de se manter firme. .

Construir uma identidade, para Erikson (1976), implica definir quem a pessoa é, quais são seus valores e quais as direções que deseja seguir pela vida, visto que a formação da identidade recebe a influência de fatores: intrapessoais, que são as capacidades inatas do indivíduo e as características adquiridas da personalidade; interpessoais, que se referem às identificações com outras pessoas; culturais, valores sociais aos quais uma pessoa está exposta, tanto no âmbito global como no comunitário.

Ao longo da vida, os indivíduos constroem sua identidade no desempenho de vários personagens. Estão sempre em busca de um, visto que têm de atender a alguns papéis sociais e situações impostas. De acordo com interesses e situações, os personagens se alteram. À medida que vivem esses personagens, transformamse para que possam sobreviver, evitando a morte simbólica, a ausência de sentido nos objetos e nas experiências. Assim, tudo há de ter um sentido e um significado, e estes são adquiridos quando as pessoas fazem suas escolhas e encontram significados para os acontecimentos, o que contribui para que a apatia perante as situações ou a loucura não se manifeste (CIAMPA, 1996).

Segundo Hall (2005), o sujeito pós-moderno, com sua identidade fragmentada, múltipla e multifacetada, pertence a diversos grupos ao longo de sua vida, com os quais se identifica ou pode vir a se identificar, independentemente de se comprometer com todos eles. No decorrer do tempo do sujeito cognoscitivo e reflexivo, diversas possibilidades vão se configurando, e, em alguns momentos, umas e outras mostram-se mais aparentes e significativas. Em cada situação a pessoa se apresentará de uma forma, deixando transparecer algumas características. Assim, nota-se que "as identidades são construídas ao longo de discursos, práticas e posições que podem se cruzar ou ser antagônicas" (HALL, 2007, p. 108).

Em sua existência, o homem pode construir (ou, às vezes, destruir) diferentes identidades, como a profissional, a de gênero ou a de pai de família. A identidade é construída por meio de papéis sociais, incluindo relacionamentos, ocupação profissional, filiação política, estigma, religião e raça (NUNAN, 2003).

Portanto, a identidade de uma pessoa pode ser vista como uma manifestação entre várias possíveis, dada a complexidade do sistema que a envolve (sociedade, cidade, país, etnia, sexo, e assim por diante) e as possibilidades e lógicas de seus atos. Dessa forma, a identidade direciona a ação e é resultado e processo da história da pessoa, de uma biografia ou autobiografia, de um conjunto de sistemas de ação, relações, processos cognitivos, influências culturais, do tempo, de decisões individuais e incertezas ambientais, de processos biológicos e psíquicos inconscientes (FERNANDES, 2006).

A construção da identidade assumiu a forma de uma experimentação infindável. Os experimentos jamais terminam. Você assume uma identidade num momento, mas muitas 
outras, ainda não testadas, estão na esquina esperando que você as escolha. Muitas outras identidades não sonhadas estão por ser inventadas e cobiçadas durante a sua vida. Você nunca saberá ao certo se a identidade que agora exibe é a melhor que pode obter e a que provavelmente lhe trará maior satisfação (BAUMAN, 2005, p. 91-92).

Assim, o processo de construção de identidade vai ocorrendo como se ela fosse um rótulo, o qual as pessoas se aplicam, comportando relações positivas de inclusão e relações negativas de exclusão. "Nós nos definimos pelas semelhanças com algumas pessoas e as diferenças com outras" (NUNAN, 2003, p. 121).

A construção da identidade é feita sempre com a integração entre elementos do presente e do passado, evitando-se, assim, uma descontinuidade. Essa ação contínua que a pessoa trava consigo mesma para estabelecer uma clara identidade é que consiste na "crise de identidade" que nada mais é que a própria busca pela identidade (ERIKSON, 1976).

Um aspecto importante para a sobrevivência está na necessidade de construção de uma identidade, uma noção de totalidade que leve a convergir em uma imagem de si mesmo as muitas facetas de um modo particular de ser, os muitos papéis representados em diferentes momentos de experiência social. Assim sendo, a pessoa vai se diferenciando e se igualando continuamente conforme os vários grupos sociais que integra, tornando-se uma unidade contraditória, múltipla e mutável. A identidade pessoal é construída na interação humana, na qual são compartilhados objetivos, regras, valores, entre outros (remete a algum sentimento atribuído ao outro) (FERNANDES, 2006).

Para Dubar (1997), a construção da identidade deve ser visualizada dentro da trama de relações discursivas e históricas, o que sugere que ela inicia-se com as experiências sociais que estruturam os discursos das pessoas nas suas práticas sociais, pois ninguém vive isolado do mundo; as interações sociais são constantes e necessárias, assim como as interações simbólicas o são para o processo de construção da identidade. As pessoas já nascem fazendo parte de uma rede social limitada, que tende a se expandir ao longo dos anos com o seu desenvolvimento.

Dessa forma, o indivíduo constrói sua identidade em sua relação diária com sua própria vida, sua cultura, estabelecendo uma tríplice relação entre identidade e trabalho, relações sociais e afetivas, que ocorre por meio de escolhas ao longo de sua vida (JACOBINA, 2006).

Para Castells (2000), a identidade é mediada pelas relações estabelecidas entre determinados grupos e construída num contexto específico:

A construção de identidades vale-se da matéria-prima fornecida pela história, geografia, biologia, instituições produtivas e reprodutivas, pela memória coletiva e por fantasias pessoais, pelos aparelhos de poder e revelações de cunho religioso. Porém, todos esses materiais são processados pelos indivíduos, grupos sociais e sociedades que reorganizam o seu significado em função de tendências sociais e Project os culturais enraizados na sua estrutura social, bem como na sua visão de tempo/espaço (CASTELLS, 2000, p. 4).

Desse modo, uma pessoa pode apresentar identidades múltiplas em um contínuo processo de autoconstrução e individualização. O único sentido da história é a história que faz sentido para a pessoa. A identidade passa a ser determinada não pelo que ela faz, mas sim pelo que ela é. "Entende-se por identidade a fonte de significados e experiências de um povo" (CASTELLS, 2000, p. 2).

Com isso, nota-se que a identidade acaba sendo entendida do ponto de vista de definições estruturais, históricas e materiais, em que homens e mulheres são socializados de uma maneira diferente no que se refere a educação, ocupação e experiências, visto que ainda existe a ideia do que é apropriado para cada sexo separadamente. Ou seja, a questão de gênero é uma das principais características da identidade pessoal e 
possui uma grande importância nas relações interpessoais e de trabalho (ALVESSON e BILLING, 1997; TABAK, 2002).

Diante de todas as ideias e conceitos expostos nesta seção, é propícia a afirmação de Silva (2007, p. 96-97):

A identidade não é uma essência; não é um dado ou um fato - seja de natureza, seja da cultura. A identidade não é fixa, estável, coerente, unificada, permanente. A identidade tampouco é homogênea, definitiva, acabada, idêntica, transcendental. Por outro lado, podemos dizer que a identidade é uma construção, um efeito, um processo de produção, uma relação, um ato performativo. A identidade é instável, contraditória, fragmentada, inconsistente, inacabada. A identidade está ligada a estruturas discursivas e narrativas. A identidade está ligada a sistemas de representações.

Considerando o acima exposto, faz-se imprescindível entender a identidade como algo que deva ser construído, mantido e reconstruído pela pessoa ao longo de seu desenvolvimento, crises e transformações. A identidade é constituída por diversos elementos, os quais formam e moldam a pessoa ao longo do tempo e espaço e tendem a ser incorporados à sua história de vida, de acordo com suas afinidades e identificações.

O indivíduo busca isso por meio do seu "caráter pessoal", que tende a ser o mesmo durante sua existência, o que o leva a se transformar no tempo sem, no entanto, perder sua "essência". Constrói, dessa forma, uma identidade coesa, conciliando passado, presente e futuro (trajetória), sempre se percebendo como a mesma pessoa, por mais que seja a todo o momento singular e plural, compreendendo, desta maneira, suas atitudes passadas e projetos futuros.

\section{Elementos constituintes da identidade}

As identidades são constituídas e transformadas de acordo com as atitudes do homem frente a novas condições sociais, econômicas, políticas e culturais. Toda experiência nova acarretará um novo ser (MORENO, 2003). Ou seja, as pessoas se transformam apresentando novos valores, avaliações e classificações, o que implica alterações no perceber, rememorar e valorizar da pessoa (STRAUSS, 1999).

A pessoa transforma-se e se constitui pelo processo contínuo de identificação com o ambiente social (ambientes, grupos sociais e ações). Dessa forma, a identidade é construída na relação com os diversos grupos dos quais o indivíduo toma parte, assim como pelo seu agir, uma vez que a pessoa é sua ação, e transforma-se por meio dela: "[...] nós somos nossas ações, nós nos fazemos pela prática" (CIAMPA, 1996, p. 64).

As relações sociais são estabelecidas pelas significações: significado e sentido; a significação transita por suas diferentes dimensões, como o pensar, o falar, o sentir, o criar, o desejar e o agir, os quais são tecidos nas relações sociais (MOLON, 1997).

Para Votre (2002), conforme o sistema de crenças e o propósito visado, o sujeito recebe e interpreta as situações, aprovando-as ou reprovando-as. Essa atitude será tomada com base nos objetos mentais por ele construídos, os quais se encontram nas cadeias significantes, que possuem sua ordem de prioridade. A decodificação das informações será sempre realizada segundo essa cadeia.

Percebe-se, por meio da literatura sobre construção da identidade, que a identidade pode ser constituída por diversos elementos. Neste artigo, os elementos constituintes da identidade pessoal utilizados como referência para a interpretação dos dados coletados foram: memória, narrativa, identidade social/grupal e trabalho/atividade, os quais estão descritos a seguir. Os dois primeiros elementos estão diretamente ligados à 
história de vida das artesãs da comunidade da Vila Rural Esperança, que foram resgatadas e narradas por elas próprias. Os outros dois relacionam-se à inserção das artesãs no projeto Seda Justa (grupo social) e à tecnologia social como atividade de trabalho.

\section{Memória}

O relato que uma pessoa faz de sua vida, quando escreve ou reflete sobre ela, é um ordenamento simbólico de episódios guardados em sua memória. Já o senso que ela tem de sua vida baseia-se em conceitos e interpretações que escolhe para usar na multidão de forma inumerável e desordenada dos atos passados. Essas interpretações são autoconvincentes, por isso a pessoa se percebe como ela mesma, pois existe algum tipo de sentido atribuído à sua vida. Assim, a memória é encarada como uma construção social (STRAUSS, 1999).

De acordo com Velho (1994), a pessoa constrói sua biografia por meio de experiências pessoais, amores, desejos, sofrimentos, decepções, frustrações, traumas, triunfos etc., com base em sua memória, indicando, dessa forma, o sentido de sua singularidade.

Bauer (2004) ressalta que a identidade interpretada no tempo presente não é comparada com a identidade do passado, mas com o seu reflexo guardado na memória e resgatado no tempo presente. Segundo ele, a memória, a identidade e a história estão interligadas no processo de construção. A memória constitui a identidade na medida em que reforça, por meio de lembranças, a unidade e continuidade de si mesmo ou o sentimento de pertencimento a um grupo. Ao mesmo tempo, a memória é constituída pela identidade, tendo em vista que o processo de identificação terá influência na seleção e configuração dos acontecimentos a serem lembrados - e reordenados em uma nova história.

A memória de cada indivíduo preserva os conhecimentos e as experiências anteriores (construções sociais passadas) como meio ativo de controle sobre sentimentos e comportamentos posteriores. Todo sujeito tende a preservar algumas experiências que lhe ocorreram, a memória tende a ser seletiva e guarda apenas os momentos de maior significância. São estas lembranças que ajudam a dar forma à pessoa adulta e a constituir aquela que será muito diferente da criança ou do adolescente que foi.

Nesse sentido, "quanto maior a margem de diferenciação nas experiências gravadas na memória dos indivíduos no curso do desenvolvimento social, maior a probabilidade de individualização" (ELIAS, 1994, p. 154).

O meio social, para Halbwachs (2004), é um ponto de referência para a evocação e localização das lembranças pessoais. Segundo o autor, não basta apenas uma sequência de pensamento delimitado no tempo e no espaço para que a pessoa recorde sua história individual; os acontecimentos precisam estar enraizados no seu "espírito", a afetividade deve permanecer para que ela encontre ali um sentido e um sentimento de continuidade no tempo.

O sentido e o sentimento de continuidade não significam que o sujeito seja imutável durante sua existência, mas que as condições de vida, o trabalho e o reconhecimento social lhe possibilitam o mesmo sentimento e valor durante sua história, ainda que seja necessário, às vezes, modificar vários de seus atributos (MENDES e ICHIKAWA, 2007).

\section{Narrativa}

Toda experiência humana é mediada pela socialização e, em particular, pela aquisição da linguagem. A linguagem e a memória estão intrinsecamente ligadas, tanto no nível da lembrança individual quanto no da institucionalização da experiência coletiva. Para a vida humana, a linguagem é o meio original e principal de 
distanciamento no tempo e no espaço, tornando possível a diferenciação de passado, presente e futuro (GIDDENS, 2002).

Toda linguagem constitui um elo que liga o presente e o passado de um indivíduo ou grupo; ela representa um sistema de códigos, cristaliza uma configuração cultural em comum que abre espaço para um sistema de símbolos compartilhado entre as pessoas que estão incorporadas ao grupo (CASTELLS, 2000).

Votre (2002) também aponta que a identidade de um ser humano se constitui na língua e por meio dela. A linguagem é um dos pilares constitutivos dos sujeitos, é marcada e demarcada por traços discursivos que os singularizam como um ser de linguagem. Suas crenças e desejos são todos tecidos na linguagem; enfim, nomeados, construídos na interação, no constante processo de (re)construção, projeto de redescrição e reformulação, num ininterrupto processo de autocriação que só ocorre na interação com outros vocabulários.

No quadro da pragmática lingüística, o sujeito tende a ser conceituado como o conjunto de enunciados, atitudes, estados, condutas ou processos intencionais formados por termos lingüísticos elementares, como: sensações, sentimentos, emoções, pensamentos e expectativas. Cada um de nós se constrói e é construído com matéria discursiva (VOTRE, 2002, p. 89).

O processo de linguagem é essencial para o desenvolvimento do eu. O eu surge no processo de experiência social e da atividade, o qual ele organiza em sua memória. As reações habituais vêm das experiências anteriores. O eu é o resultado de suas relações nesse processo como um todo (MEAD, 1972).

As identidades pessoais são construídas e reconstruídas nas relações com o contexto interno e externo, que estão num constante fluxo, por meio das narrativas, da ação social e de interações interpessoais e institucionais. E são constituídas pelo entrelaçamento da história, de narrativas, discursos, conhecimento social e relacionamentos, bem como por práticas institucionais e culturais.

A identidade como narrativa está dentro do tempo e espaço, remete às relações e histórias das pessoas, demonstrando que a identidade não é algo fixo e, sim, algo contínuo como a ação. A identidade narrativa supõe que a abordagem da ação social só pode ser compreensível se reconhecermos que as pessoas são orientadas a agir pelas relações em que estão e pelas histórias com as quais se identificam, e raramente por causa dos interesses que lhes foram colocados (normas sociais) (SOMERS e GIBSON, 1995).

As experiências de vida possibilitam uma narrativa de como a pessoa é. Ou seja, ela procura entender o que aconteceu e o que está acontecendo pela tentativa de reunir ou, de alguma forma, integrar os acontecimentos dentro de uma ou mais narrativas que estão imersas no tempo e no espaço - o que torna a constituição da identidade uma operação narrativa.

Desta forma, as pessoas são conduzidas a certos caminhos e não a outros, baseadas nas projeções, expectativas e memórias derivadas da multiplicidade de repertórios de narrativas sociais, públicas e culturais que estão disponíveis. A característica central da narrativa é propiciar compreensão pela conexão das partes numa configuração construída ou numa rede social composta de práticas simbólicas, institucionais e materiais (SOMERS e GIBSON, 1995).

Segundo Oliveira e Bastos (2001), a pessoa, ao contar sua história, apresenta-se, já que transmite às demais o sentido de quem é, suas crenças e seus valores. Dessa forma, constrói narrativas de experiência pessoal ou de histórias de vida que colaboram para a criação e manutenção das identidades pessoais, visto que, ao narrar suas histórias, o sujeito mostra como se tornou o que é e transmite aos demais o que devem saber sobre ele para conhecê-lo melhor.

Da mesma forma, para Lopes (2001), a pessoa, ao narrar a sua história aos outros e a si mesma, constrói a sua história de vida e atribui sentido à sua vida, entendendo a forma como foi construída no mundo social - 
salientando-se que a narrativa tem lugar em dois mundos: aquele onde se passou a história e onde ela está sendo narrada agora, podendo se entrecruzar.

\section{Identidade grupal ou social}

De acordo com Strauss (1999), não se pode considerar a questão da identidade pessoal sem levar em conta a identidade social, visto que as identidades pessoais e sociais se constituem reciprocamente. Segundo o autor, as identidades sociais são historicamente elaboradas, atuando nas identidades pessoais como memória permanente atualizada (autorreflexão, interação, afiliação, simbolismo e mundo social), formadas pela tríade: sujeito, sociedade e trabalho.

O conceito de identidade pessoal e o de identidade social possuem um conteúdo reflexivo ou comunicativo, uma vez que supõem relações sociais tanto quanto um código de categorias (valores, caráter ideológico e cultura) destinado a orientar o desenvolvimento (identidades: mantidas, construídas, reafirmadas e/ou ressignificadas). Para orientar esse processo é fundamental a apreensão dos mecanismos de identificação (OLIVEIRA, 2007).

Para uma pessoa se identificar, não precisa despender esforço; só precisa perceber-se como psicologicamente entrelaçada com a sorte/destino do grupo. Isto ocorre quando há a internalização, que corresponde à aderência aos princípios orientadores como valores, normas e comportamentos grupais, o que torna homogêneos pensamentos e atitudes dos membros. O comportamento e o laço afetivo (significação valorativa e emocional) são vistos como potenciais antecedentes ou consequentes da vinculação grupal (ASHFORTH e MAEL, 1989).

Para Ashforth e Mael (1989), à medida que os membros se identificam com a organização, têm a percepção de unicidade com o grupo e passam a responder parcialmente a pergunta: "Quem sou eu?" Quando isso ocorre, os membros assumem um caráter distintivo e de prestígio do grupo, o que afeta a sua autoestima, que está associada a lealdade, orgulho do grupo e de suas atividades, por estarem coerentes/congruentes com sua identidade, tomando para si as experiências de sucessos e de fracassos do grupo.

A identificação tende a aumentar, caso se trate de um grupo de prestígio. Os autores acima citados constataram que, devido a essa identificação, hostilidades surgem mais facilmente entre grupos do que entre sujeitos, na medida em que há concorrência e disputa entre os grupos como uma forma de os membros fortalecerem suas identidades.

A identidade social refere-se aos conceitos que a pessoa desenvolve sobre si mesma e que decorrem de sua afiliação em categorias ou grupos emocionalmente significativos para ela, o que inclui as identidades por afiliação étnica ou cultural, de gênero, de orientação sexual, de classe social, de idade ou profissionais e assim por diante. É com base nessa aglutinação de categorias da pessoa que a identidade social se torna possível ou é formada (FERNANDES, 2006).

A identidade social está associada à percepção de partilha (sentir-se parte de algo), de normas grupais, que englobam os valores, as representações e comportamentos. Quanto maior a identificação do sujeito com estas normas, mais ele as seguirá e as adotará, pois estarão incorporadas nele (VALA, 2004).

Ao compartilhar objetivos, regras, valores, entre outros, as pessoas assumem comportamentos grupais moldados pelas socializações secundárias - que, no caso, pode ser o ambiente de trabalho -, motivadas pela redução da incerteza de como devem sentir, agir, pensar e, ainda, de como serão vistas pelos outros. $\mathrm{O}$ indivíduo deverá internalizar este conjunto de significados atribuindo-lhes consistência, justificativa e legitimidade. A função do grupo é definir papéis e, consequentemente, a identidade social de cada um. Assim, a identidade passa a ser entendida como o próprio processo de identificação (FERNANDES, 2006). 
As normas do grupo, os valores e as condutas são progressivamente interiorizados, mas a identidade pessoal não é mero "decalque" das identidades sociais existentes, pois também inclui os atributos pessoais, os relacionamentos, as fantasias, as posses, a vida familiar, a saúde, a solidariedade, a atividade criativa e os sentimentos relacionados a todos esses atributos simbólicos que a pessoa utiliza para se conceituar e se situar no mundo (FREITAS, 2002).

De acordo com Hall (2007), a identificação é construída pelo reconhecimento de alguma origem comum (semelhança), ou de características que são partilhadas com outros grupos ou pessoas, ou ainda por um ideal, formando-se, assim, a solidariedade e a fidelidade grupal. No entanto, o autor salienta que nunca há um ajuste completo, uma vez que a diferença entre os membros do grupo persistem.

Da mesma forma, Maheirie (1997, p. 65) afirma que "a construção de uma identidade coletiva se faz pela unificação das diferenças em torno de um projeto em comum". O homem interioriza significações com valores, ideias e a própria ideologia presente. Todas essas subjetividades serão objetivadas em suas ações individuais ou grupais. Por isso, o homem é subjetividade e objetividade ao mesmo tempo e constantemente.

Assim sendo, as identidades sociais seriam formadas por prática, ação e posicionamento mútuo entre as pessoas e, também, por direitos normativos, obrigações e sanções que acabam por constituir papéis a serem assumidos. Desta forma, a identidade social é mais do que a concepção individual de si mesmo, pois depende de reconhecimento e legitimação dos outros que compõem a realidade social do sujeito, havendo, assim, uma interdependência entre a realidade interna e externa (BERGER e LUCKMAN, 1985).

Velho (1994) menciona que um projeto coletivo não é vivido de modo totalmente homogêneo pelos integrantes que o compartilham, visto que cada um interpreta e encara o projeto de uma forma, de acordo com suas particularidades de status, trajetória, família, gênero, geração e assim por diante.

Desse modo, a identidade se refere à inserção do homem numa categoria social (grupos de referência), como gênero, raça, idade ou orientação sexual, por exemplo, e mecanismos socializadores como família, etnia, região, vizinhança, religião etc. Quando deslocada dessa situação social que a ativa, essa identidade pode tornar-se oculta.

\section{Procedimentos metodológicos}

Para este artigo foi realizada uma pesquisa descritiva de natureza qualitativa, que, de acordo com Triviños (1987), é, de per si, descritiva. Assim, com recurso a ela, é possível descrever, criteriosamente, fatos e fenômenos de determinada realidade, de forma a obter informações a respeito do que já se definiu como problema. Aqui se procurou compreender de que forma a tecnologia social contribuiu para o processo de construção e constituição da identidade das artesãs da comunidade da Vila Rural Esperança. E, assim, conseguiu-se elucidar algumas "inquietações" pela riqueza de detalhes que o contato com as participantes da pesquisa proporcionou.

Antes de iniciar a pesquisa foi realizado um primeiro contato informal, por telefone, com o coordenador da EMATER - PR (Empresa de Assistência Técnica e Extensão Rural) no mês de julho de 2008, para apurar a possibilidade de acesso à comunidade da Vila Rural Esperança, ao projeto Seda Justa e às artesãs dessa comunidade. Então, foi solicitada a autorização para realizar esta pesquisa com as artesãs da comunidade da Vila Rural Esperança.

O coordenador da EMATER garantiu o acesso às artesãs, autorizou verbalmente a pesquisa na comunidade da Vila Rural Esperança e se colocou à disposição. Esta instituição governamental foi procurada, visto que é uma das parceiras do projeto Seda Justa, e colaborou para a implantação do projeto na comunidade. 
No mês de junho de 2009, foi feita uma visita informal à comunidade da Vila Rural Esperança, guiada pelo coordenador da EMATER, para conhecer a artesã responsável pelo projeto Seda Justa na comunidade. Essa artesã repassou seu conhecimento e técnica do tricô às demais. Nessa visita se falou a respeito da pesquisa que se pretendia fazer.

A artesã concordou em participar da pesquisa e se colocou à disposição para fazer as devidas apresentações às demais integrantes do projeto, bem como em conversar previamente com estas sobre as entrevistas. Com isso, obteve-se uma visão panorâmica do local e da população, o que contribuiu para a preparação da coleta dos dados primários, que ocorreu no segundo semestre de 2009.

Para este estudo foram contempladas todas as artesãs (população total) que fazem parte do projeto Seda Justa, visto que as 09 (nove) estão inseridas nele desde o início das primeiras confecções. Isso possibilitou apreciar as várias percepções a respeito dos efeitos da tecnologia social sobre a identidade, de modo que abrangesse especificidades diferentes, tais como: visões de mundo, experiências e histórias de vida. Procuradas para participar da pesquisa, as artesãs concordaram em fazê-la. Dispuseram de tempo e se mostraram interessadas em participar do estudo. Foi utilizado como instrumento de coleta de dados a entrevista aberta e o método da história de vida.

Assegurou-se o anonimato às artesãs para que não se sentissem expostas ou constrangidas. Desse modo, foram aqui identificadas por intermédio de nomes fictícios e, por tratar-se de mulheres, escolheu-se um nome de flor para cada uma, no intuito de que não houvesse inibição por parte delas no relato de sua história de vida. Acredita-se, assim, que as perguntas realizadas nas entrevistas foram respondidas de forma espontânea e sincera.

As entrevistas foram realizadas pessoal e individualmente e ocorreram no ambiente natural das artesãs, ou seja, na comunidade da Vila Rural Esperança, em suas próprias residências (propriedades rurais). As entrevistas foram aplicadas de maneira que as artesãs respondessem as questões colocadas de forma livre e com a abrangência necessária, seguindo, na medida do possível, o roteiro traçado.

Considerando o momento em que os dados foram coletados, o horizonte de tempo desta pesquisa é transversal ou seccional, pois a coleta limitou-se a apenas um período de tempo. Segundo Vieira (2004), quando o interesse é o momento atual, sobre o qual os dados são coletados, a pesquisa caracteriza-se como transversal ou seccional.

Por meio da hermenêutica, buscou-se interpretar as 06 horas e 12 minutos de entrevistas gravadas, que resultaram em 45 páginas de transcrição de áudio. Foram 09 entrevistadas e 23 guias de ordem geral utilizados como norteadores para a obtenção das respostas desejadas.

Segundo Gadamer (1997), a hermenêutica baseia-se no princípio de que as partes de um texto só podem ser entendidas no todo, e vice-versa. Menciona, ainda, que se tem de compreender cada época por si mesma e não por um presente estranho a ela. Pois, para se compreender, deve-se, primeiramente, entender o assunto dentro de seu contexto. A pré-compreensão é fundamental a uma compreensão coerente. Primeiro, há de se ter o conhecimento a respeito do assunto. A forma de realização da compreensão é a interpretação por meio da linguagem, tanto escrita como oral. Compreender é a aplicação de algo geral a uma situação concreta e particular; implica a possibilidade de interpretar, detectar relações e extrair conclusões em todas as direções, que é o que constitui o entender.

\section{Interpretação das histórias de vida narradas pelas artesãs}

Mediante o resgate das histórias de vida das artesãs, foi possível perceber o que elas valorizam, pensam, sentem e fazem. O que se pode afirmar é que as artesãs possuem identificações comuns que servem como referenciais, tais como gostar de morar no sítio, onde já haviam morado anteriormente; possuir raízes no 
campo; apreciar trabalhar no meio rural, pois se identificam com o lugar; imagem positiva que os pais deixaram, o que pode ter sido absorvido consciente ou inconscientemente da família. Muitas das entrevistadas já conheciam a atividade de tricô, são donas de casas, e a grande maioria possuía experiência na criação do bicho-da-seda e a necessidade de trabalhar para se sentir útil. Extrai-se, também. das declarações obtidas, que há um desejo pelo bem das pessoas que moram na comunidade e de que a cooperativa seja bem-sucedida.

Esta identificação chama a atenção, visto que, segundo Lopes (2001), o indivíduo, ao narrar sua história aos outros e a si mesmo constrói a sua história de vida e atribui sentido à sua vida, entendendo a forma como foi construído no mundo social. Ao pensar sobre si, recupera, por meio da memória, situações vividas que lhe foram relevantes.

Houve algumas identificações em comum: a maioria das artesãs enfatizou gostar da confecção de cachecóis na agulha e no tear - trabalho genuinamente manual, no qual imperam o aprendizado e a atividade em grupo - e de conciliá-la com os serviços domésticos. A atividade preenche o tempo das entrevistadas, ajudando-as a distraí-las, uma vez que quase não saem de casa e, além disso, pode ser realizada em suas próprias residências, o que facilita conciliar os papéis de artesã, dona de casa, mãe e esposa. Há, assim, um respeito à cultura local, à manutenção do modo de vida tradicional, percebendo-se que as entrevistadas não fazem uma separação entre seu local de trabalho e sua moradia.

O que vai ao encontro da proposta da tecnologia social, na qual os participantes devem estar envolvidos na busca por uma tecnologia que seja compatível à sua realidade e aos seus conhecimentos, e que solucione, assim, seus problemas.

Confirmou-se que o trabalho das entrevistadas é pautado, sobretudo, por simplicidade, baixo custo, fácil aplicabilidade e impacto social. O que remete a Lassance Junior e Pedreira (2004), segundo os quais a comunidade é quem escolhe a tecnologia, o produto ou os serviços finais, respeitando sua cultura e possível capacitação local, os quais possuem proporção de pequena ou média escala e fazem uso de recursos renováveis ou naturais, de maior intensidade de mão de obra.

As artesãs possuem liberdade na escolha de como fazer seus produtos - cada uma os faz a seu modo. Procuram uma forma na qual se adaptem, que as deixem satisfeitas e rápidas no tricotar: assim a confecção "rende mais" e elas sentem menos dificuldades em sua atividade.

Há identificação com o trabalho, visto que este faz sentido para elas. Assim, atendem ao papel que assumiram no ambiente de trabalho e às expectativas de seu grupo social, construindo e reconstruindo, dessa forma, sua identidade pessoal, por meio da atividade e de seus colegas de trabalho.

A tecnologia social contribuiu para o processo de construção e constituição da identidade das artesãs da comunidade da Vila Rural Esperança, por meio do significado do trabalho artesanal como fonte de autoestima, autorrealização e geração de renda.

O maior benefício trazido pelo projeto Seda Justa, segundo a maioria das entrevistadas, foi de cunho financeiro - com o aumento da renda familiar, conseguiram comprar e pagar bens materiais. Em seguida vem a ocupação: tornaram-se mais ativas e valorizadas por estarem desenvolvendo uma atividade cujos produtos são exportados. Isso, além de reportagens e visitações, elevou sua autoestima e incentivou a produção dos criadores. Sentem-se honradas por pessoas tão distantes comprarem seus produtos.

O reconhecimento internacional tornou possível o nacional, pois o contato da comunidade da Vila Rural Esperança com o meio externo surgiu com a comercialização dos produtos para a França, por meio do sistema de comércio justo. 
Os benefícios mencionados são os efeitos positivos gerados pela tecnologia social citados por Dagnino, Brandão e Novaes (2004), como: geração de renda, emprego, relações sociais e meio ambiente.

A opinião das artesãs quanto aos benefícios divergem, isso porque, segundo Velho (1994), o projeto coletivo não é vivido de modo totalmente homogêneo pelos integrantes que o compartilham. Cada integrante interpreta e encara o projeto de uma forma, de acordo com suas particularidades de status, trajetória, família, gênero, geração e assim por diante.

As artesãs ressaltam que as francesas compram seus produtos por eles serem naturais, feitos com um artigo de qualidade como a seda, por preferirem produtos artesanais e por estarem de acordo com os propósitos do sistema do comércio justo, valorizando, assim, o produtor rural. Com isso, a exportação dos produtos pelo sistema de comércio justo lhes rendeu prestígio e uma boa reputação dentro e fora do país, o que pode ser constado no fragmento abaixo:

Eu acho que é uma novidade, um produto assim, todo natural que eles têm conhecimento desde o primeiro projeto até o acabamento, eles sabem que aqui a gente planta amora, toca o bicho, faz o fio. [...] É, eu acho que estão com consciência de mudança de mundo, de melhorar e estão querendo dar uma forcinha para as pessoas. Além deles terem uma novidade também. (senhora Amarílis)

De acordo com Rutkowski e Lianza (2004), a tecnologia social postula o uso racional dos recursos naturais, visto que estes são esgotáveis, como forma de melhorar a qualidade de vida dos habitantes. Busca-se o desenvolvimento sustentável como forma de equilíbrio entre o desenvolvimento e a preservação dos recursos naturais.

As tecnologias sociais são alternativas de desenvolvimento cuja origem está em experiências inovadoras, que tendem a ser locais, mas que podem ter repercussão em nível nacional e se expandir por meio das redes (DAGNINO, 2008).

O sucesso desse tipo de empreendimento depende da estruturação dos procedimentos e métodos das tecnologias sociais em modelos flexíveis para que estas possam ser reaplicadas. Nem tudo que é viável em um lugar pode o ser em outro. Por isso é importante a possibilidade de se fazerem adaptações. A tecnologia social não poderá se disseminar se não houver um padrão tecnológico cujos elementos essenciais permitam escala. Esse padrão pode ser um programa de formação e capacitação (LASSANCE JÚNIOR e PEDREIRA, 2004).

As artesãs estão conseguindo atribuir significados e sentidos à sua atividade por meio da ação e das relações sociais que estabelecem, o que, segundo Ciampa (1996), colabora para a formação e objetivação de suas identidades.

Os depoimentos coadunam-se com o que Giddens (2002) menciona: o desempenho de atividades na vida cotidiana responde a questão do ser, por meio da ação e de acordo com o propósito de cada um, constituindo uma trajetória, indicando um percurso.

Grande parte das artesãs notou mudanças na comunidade da Vila Rural Esperança com o surgimento do projeto Seda Justa. Entre elas a valorização da própria comunidade da Vila Rural Esperança, que se tornou mais conhecida fora de seu meio, por intermédio de reportagens e visitas frequentes, inclusive internacionais, o que suscitou um grande interesse da mídia da região. Segundo as entrevistadas, com a existência do projeto Seda Justa houve a união das artesãs e dos criadores do bicho-da-seda. As artesãs tornaram-se mulheres mais ativas; já os criadores sentiram-se mais incentivados em sua atividade. Assim, os que compartilhavam do mesmo ideal uniram-se e acabaram por excluir os "diferentes", ou seja, aqueles que não se engajaram no projeto. 
No depoimento da senhora Violeta fica clara a relação hierárquica nas parcerias existentes, visto que as artesãs não podem comprar fios mais baratos para confeccionar e vender a particulares. Há uma relação de dependência: o progresso delas está atrelado aos parceiros. Existe, por parte das artesãs, uma maior valorização da matéria-prima do que do próprio trabalho de confecção. No entanto, as tecnologias sociais se utilizam de matérias-primas renováveis e pregam, acima de tudo, o desenvolvimento humano, sendo contra a relação patrão-empregado e apregoando que todos os envolvidos devem estar no mesmo nível hierárquico.

[...] Particular não, porque o fio, a seda é da Seda Justa, então é só eles lá que fazem os fios. Então nós é comandado mais por eles, com parceria com eles. Nós só fazemos, já sobre a linha e essas coisas é com eles lá. (Violeta)

O consultor dos produtores da comunidade da Vila Rural Esperança foi mencionado como o "chefão" do projeto Seda Justa. Já a senhora Alice, responsável pelo projeto Seda Justa na comunidade da Vila Rural Esperança, mencionou o vice-presidente da comunidade da Vila Rural Esperança como aquele que determina o que deve ser confeccionado. Inclusive, sem notar, umas das entrevistadas, a senhora Jasmim, incorporou em alguns momentos o discurso do outro.

A proposta da tecnologia social é desenvolver e disseminar uma tecnologia que seja: não promovedora do controle, da segmentação, hierarquização e dominação nas relações patrão-empregado, e incentivadora do potencial e da criatividade dos usuários e capaz de viabilizar economicamente os empreendimentos como cooperativas populares (RTS, 2008, p. 19).

A estrutura de trabalho e a estrutura hierárquica são claras:

É com organização, no projeto não é cada um que faz de acordo com sua vontade não. Tem uma organização lá que o seu João organiza e traz daí para nós o que ele quer e nós fazemos. [...] Ele traz a lã, o fio já pronto para nós, traz os teares também, ele que arrumou para nós. [...] Nós estamos fazendo em casa. [...] Não, nós só se reúne quando tem alguma dúvida para aprender alguma coisa, a gente se reúne aprende, ensina uma para a outra, daí cada uma vai fazendo em casa. E o bom deste projeto é este, que a gente pode fazer nas horas de folga, nas horas vagas. É muito bom fazer em casa. (senhora Amarílis)

O ambiente de trabalho é um espaço ao mesmo tempo socializador e socializado, um meio de reconhecimento e de ação, onde as pessoas sofrem efeitos transformadores em virtude dos papéis que incorporam e das relações que estabelecem.

Segundo Mariga (2004), a busca pelos conhecimentos técnico-científicos compete aos próprios interessados para que estes se tornem sujeitos-ativos da própria história e para que não a contemplem ou a descrevam apenas. Isto ocorre por intermédio de ações e avaliações destes interessados sobre a realidade, o que implicará busca por novos conhecimentos que os capacitem a uma atuação mais crítica, consciente, confiante e independente, para que pratiquem inteiramente a cidadania.

A troca de conhecimento entre os atores envolvidos nos processos é um dos objetivos da tecnologia social, bem como a identificação de novas oportunidades estratégicas, constituindo-se num processo contínuo de aprendizado e surgimento de novas ideias.

Percebeu-se, por meio das narrativas, que as artesãs estão na fase de aprendizado. As novas tarefas lhes têm proporcionado satisfação e realização pessoal. No entanto, ainda buscam a realização profissional, pois, quando se referem ao seu trabalho, lamentam que este seja apenas sazonal - almejam que se torne permanente. E, também, com o início da cooperativa, as entrevistadas mencionaram que o trabalho permanente se tornará possível, o que, segundo elas, melhorará a qualidade de vida de todas as envolvidas. 
Nota-se que as artesãs estão dispostas a trabalhar, a aprender tarefas novas e que estão envolvidas nas atividades do projeto Seda Justa. Salientaram gostar de todos os trabalhos realizados até o momento; esperam que a demanda por seus produtos aumente, o que demonstra identificação com o trabalho desenvolvido. As entrevistadas estão aproveitando a oportunidade de trabalho, de renda e a comodidade de morar e trabalhar no mesmo local.

Do depoimento da senhora Violeta, extrai-se que ela identifica algumas artesãs como mais dedicadas e rápidas do que outras, o que denota uma diferenciação entre elas (membros do grupo) e que não há totalidade de grupo: nem todos são tratados como iguais no projeto Seda Justa.

Olha, aqui o projeto está em três: eu, a dona Alice e a Lídia, aí então nos três, aí vem as outras junto com nós, mas aí cada uma faz o seu, mas então as mais fortes no trabalho aí é eu, a dona Alice e a Lídia, que nós é que está no meio da cooperativa e depois vem as outras. (senhora Violeta)

As entrevistadas apresentam um senso de união grupal. São solidárias entre si e, apesar de se relacionarem muito bem, suas relações são restritas ao projeto, o que acaba por estabelecer um elo fraco de amizade.

[...] Ah, a gente se dá bem. [...] É na sua própria casa. A única pessoa que a gente tem mais contato assim é com a dona Alice, porque é ela que toma conta do projeto. [...] Mas as outras, assim, a gente quase não tem muito contato. (senhora Margarida)

Por serem donas de casa, tendem a permanecer em casa com a família, restringindo-se aos seus lares e vidas pessoais. Esse estilo de vida prioriza os laços familiares. As entrevistadas não frequentam a casa uma das outras, o que reforça o coleguismo existente e não a amizade entre elas. O relacionamento entre as artesãs se resume ao projeto Seda Justa; apenas as que possuem religião comum é que desenvolvem outra atividade conjunta.

O grupo das artesãs formou-se em virtude de uma política pública de apoio ao desenvolvimento local direcionada ao mercado de trabalho e à inclusão social denominada tecnologia social. Esta estruturou uma coletividade de interesses em torno de objetivos comuns. Todos os membros grupais possuem identificações e se mantêm por um laço comum.

De acordo com Hall (2007), a identificação é construída pelo reconhecimento de alguma origem comum (semelhança), ou de características que são partilhadas com outros grupos ou pessoas, ou ainda em virtude de um ideal, formando-se, assim, a solidariedade e a fidelidade grupal. No entanto, o autor salienta que nunca há um ajuste completo, uma totalidade, já que a diferença entre os membros do grupo persiste.

Da mesma forma, Maheirie (1997, p. 65) afirma que "a construção de uma identidade coletiva se faz pela unificação das diferenças em torno de um projeto em comum". O homem interioriza significações com valores, ideias e a própria ideologia presente. Todas essas subjetividades serão objetivadas em suas ações individuais ou grupais. Por essa razão, o homem é subjetividade e objetividade ao mesmo tempo e constantemente.

Em face ao exposto, existe o senso grupal/conotação de grupo, visto que, para se identificar, o indivíduo não precisa despender esforço; só precisa perceber-se como psicologicamente entrelaçado com a sorte/destino do grupo. Isso ocorre quando há a internalização, a qual corresponde à aderência aos princípios orientadores, como valores, normas e comportamentos grupais, o que leva a que os membros tenham pensamentos e atitudes homogêneas. O comportamento e o laço afetivo (significação valorativa e emocional) são vistos como potenciais antecedentes ou consequentes da vinculação grupal (ASHFORTH e MAEL, 1989). 
Alguns conflitos internos já ocorreram, mas não de forma declarada, devido à falta de padronização das confecções por algumas artesãs no início e também por algumas delas acharem que outras estavam sendo mais procuradas e valorizadas.

[...] Tem o padrão, é pra fazer o padrão, por que umas mulher faz e outras não faz, não é verdade!? Tem pessoas que faz, num lugar tá de uma largura, no outro tá bem estreito. É uma coisa muito... fica feio. (senhora Jasmim)

Houve também conflitos externos decorrentes do fato de algumas pessoas não se interessarem quando do início do projeto, mas mudarem, com o seu crescimento e a repercussão das reportagens, desejando nele ingressar e comentar o comportamento das artesãs já inseridas.

[...] Ah, teve sim, teve porque as pessoas acharam que a gente não ía aparecer muito, sabe!? Depois que nós começamos a aparecer muito na televisão. [...] O povo sabe, fica falando os que não se interessou no começo. [...] Quem está fora do projeto, aí chega até nós, e a gente fica até meio revoltado porque a gente não quer isso. A gente queria tudo reunir, tudo igual, mas daí igual tem muito pouco. [...] Mas as forte mesmo, é eu e a dona Alice. Nós duas desde o começo, nós pode botar serviço e o que for, não tem quem segure nós, porque eles falam: Vocês têm que estar lá, vocês têm que estar lá e vai. Nós duas vai. [...] É, nós duas as representantes. [...] Às vezes as pessoas chegam mais em mim e na dona Alice ou na Lídia, aí conversa mais. As outras falam e acham que não é justo, não é certo só conversar, porque elas também fazem, mas daí, eles mais se interessa assim em conversar com nós, porque nós que começamos, as primeiras que começou, que vêm vindo e elas vêm vindo depois, então aí nós tentamos explicar para elas, aí que elas vão entender, e falam: Aí tá certo, eu que estava nervosa, que estava irritada. [...] Ah, sim, rola um ciúmes sim e como rola. Então, a gente fica assim, eu mesma não quero isso, eu quero do jeito que eu sou, eu quero as outras também igual, porque nós somos iguais. (senhora Violeta)

Aquelas que participam do projeto Seda Justa são vistas como iguais. As que não participam acabam sendo excluídas automaticamente. Segundo Silva (2007, p. 82), a identidade é relacional e está sempre ligada a uma forte separação entre nós e eles. O mundo é dividido e ordenado em grupos e classes, e "dizer 'o que somos' significa também dizer 'o que não somos'. A identidade e a diferença se traduzem, assim, em declarações sobre quem pertence e sobre quem não pertence, sobre quem está incluído e quem está excluído". Observar a identidade de forma relacional significa reconhecer a importância do outro na composição de si, pois é só por meio do outro que a identidade pode ser percebida como singular, quanto maior for a diferença entre si e os outros.

Inicialmente, a exposição das artesãs na mídia gerou desconforto. Causou estranheza o fato de elas estarem participando de um mundo diverso daquele em que estavam inseridas. A senhora Violeta, em seu depoimento, ressalta que as pessoas zombavam de todas as integrantes do grupo por estarem aparecendo na televisão. Somente depois de muito tempo, as filmagens tiveram um reflexo positivo. Segundo a artesã, ela não teve incentivo nem apoio da família para entrar no projeto Seda Justa, todavia a influência familiar não interferiu no seu modo de agir ou pensar.

Para Erikson (1976), com o passar do tempo, quando a pessoa já se encontra na fase adulta, tende a olhar mais para si do que para o exterior. Sempre busca aquilo que lhe agrada, que a identifica. Preocupa-se menos nessa fase da vida com as opiniões alheias e protótipos a serem seguidos, caminhando, assim, para a conformação do eu, rumo ao processo de individuação, por meio do qual se torna mais um ser único e reflexivo do que um ser grupal. Isso se dá em virtude de a pessoa estar com o seu sentimento de identidade mais desenvolvido e valorizar mais o modo em que é parecida ou diferente das demais pessoas, assim como de reconhecer melhor suas limitações e habilidades. 
Um elemento importante a ser observado nas narrativas é que houve, no início, comentários negativos por parte de muitas pessoas que não acreditavam no futuro do projeto Seda Justa. Com o decorrer do tempo e com o seu crescimento e repercussão, essas pessoas começaram a se interessar e a elogiar o projeto observa-se, aí, que houve um conflito externo. Apesar de tudo, atualmente as artesãs se sentem bem em fazer parte do projeto Seda Justa. Sentem-se reconhecidas e valorizadas pela comunidade, pois são identificadas por onde passam. Dessa forma, o projeto Seda Justa lhes trouxe um prestígio pessoal; o reconhecimento dos outros.

Então, aqui na Vila o pessoal já se acostumou um pouco, mas na cidade já me pediram até autógrafo, na cidade está todo mundo perguntando. [...] Todo mundo quer participar. [...] Está todo mundo surpreso. [...] Ah, então, às vezes eu me surpreendo também, porque eu não achei que o nosso produto fosse chegar tão longe, até lá em Paris também, eu me sinto bem, eu me sinto feliz em saber que estou participando. (senhora Amarílis)

Ah, eles falam que é uma coisa boa. Muita gente fala: É bom demais! [...] Alguém na cidade já falou para mim quando surgiu a primeira gravação, filmagem, aí que as pessoas viram e conheceram a gente, e daí falou: Nossa que coisa boa que estão fazendo, queria entrar nisso também! [...] Ah, eu senti bem, senti bem, porque elas elogiaram. (senhora Clematite)

A gente tem bastante incentivo, inclusive vem atrás da gente. Eles comentam um com o outro que eu faço cachecóis, me ligam na minha casa, se eu tenho cachecol aqui pronto para poder entregar para eles, mas não é bem assim, tem todo aquele processo que vem de lá do casulo para depois chegar aqui e ser repassado para a gente. Então, os comentários que eu já ouvi são todos bons. [...] Eu sinto muito bem, porque a gente sente que é um incentivo para gente não desanimar. No início quando eles vieram fazer aqui, alguns disseram que isso não ia para frente, a gente está vendo que cada vez que está passando, a gente está vendo aquilo que a gente sonhava. [...] Achavam que era uma conversa política, essas coisas. [...] Quando reconhecem a gente, eles falam: Eu vi você na TV. [...] Teve esta reunião no início, não quiseram participar, outras foram, mas desistiram, achavam que não ia para frente, sentem ciúmes, porque não se sentiram incentivadas para poder ir atrás, a gente vê que tem um pouco de frustração, mesmo assim se demonstram felizes de estar vendo a gente feliz. (senhora Íris)

As artesãs sentem-se prestigiadas por pertencerem ao projeto Seda Justa e por serem convidadas para filmagens, consideradas como um lado bom do trabalho, já que por intermédio delas outras pessoas passam a reconhecê-las como pessoas e profissionais.

[...] Ai, eu fico legal, fico bonita, fico mais orgulhosa, porque a gente nunca sai, nunca passa e nós passamos. E eu saio na rua assim, daí eles falam: Ai, eu vi a senhora lá na televisão. O outro: Ai, eu vi. O outro: Eu vi (risos). (senhora Camélia)

Para Ashforth e Mael (1989), à medida que os membros se identificam com a organização, têm a percepção de unicidade com o grupo e passam a responder parcialmente a pergunta: "Quem sou eu?". Quando isso ocorre, os membros assumem um caráter distintivo e de prestígio do grupo, o que afeta a sua autoestima, que está associada a lealdade, orgulho do grupo e de suas atividades por estarem coerentes/congruentes com sua identidade, tomando para si as experiências de sucessos e de fracassos do grupo. A identificação tende a aumentar caso se trate de um grupo de prestígio. 
Uma das entrevistadas, a senhora Violeta, lembra que os encontros são sempre divertidos, o local de trabalho tornou-se, para elas, um espaço de trabalho e diversão. Nesses momentos, as artesãs aproveitam para "colocar a conversa em dia", trocar experiências e fortalecer os laços culturais comunitários e de grupo. Segundo as artesãs, o relacionamento entre elas e os parceiros é bom, divertem-se juntos e todos se ajudam por meio de orientações de aprendizagem. As artesãs mencionaram não possuir contato com todos os parceiros. Alguns, como as fiações, são intermediados pelo consultor da comunidade da Vila Rural Esperança. Tais situações reforçam o encontrado na literatura sobre as parcerias serem a base das tecnologias sociais.

É bom, é animado, é muito divertido! Nossa, é divertido! A gente se dá muito bem, nossa! É assim que a gente tem que ser, porque é animar e não entristecer. [...] mas nós rimos, nós brincamos. (senhora Violeta)

Todas as artesãs afirmaram que se sentem felizes por trabalhar no projeto Seda Justa. Salientaram que agora estão muito mais felizes do que antes, quando este não existia ali na comunidade da Vila Rural Esperança. Ressaltaram que, por meio do projeto, preencheram o tempo vago exercendo uma atividade que gostam de desempenhar, passaram a se reunir mais e a se sentir mais importantes e úteis, obtiveram uma renda extra, aprenderam novas coisas, desenvolveram novos laços de amizade.

Eu me sinto. [...] Ah, porque é uma coisa assim, é gostoso, que passa o seu tempo, você está fazendo alguma coisa e passando o seu tempo, e te ajuda financeiramente também. É um dinheiro que entra a mais. (senhora Margarida)

Gosto, gosto muito. [...] Ah, depois que nós entramos, a gente tem uma coisinha para fazer, a gente se reúne mais. (senhora Camélia)

[...] Só de ser o que eu sou agora, eu estou muito feliz, porque eu nunca imaginei na minha vida que ia passar eu me assistindo na televisão, que nem eu vejo na novela, vejo no Globo Repórter. [...] Ah, não, antes eu não era nada, agora eu sou alguma coisa, não é não!? Porque pelo menos o povo me conhece já, já conhecia, os outros conhecidos falam para mim: Nossa! Chegam perto de mim, nossa, me põem eu lá em cima, nossa, eu fico feliz. Eu fico tão feliz com aquilo! (senhora Violeta)

Eu sinto. [...] Acho que a gente se sente mais feliz, é igual eu falei para você, a gente fica mais feliz porque a gente se sente útil. (senhora Íris)

Além de incorporarem o projeto Seda Justa aos seus projetos de vida, as entrevistadas possuem esperanças e expectativas com relação ao referido projeto. Há uma grande motivação interna presente nas participantes. A autoestima cresceu com o projeto Seda Justa, devido ao reconhecimento dos outros, o que as levou a sentir orgulho de si mesmas e a se valorizar.

Portanto, o trabalho é uma referência importante para o sujeito, é um local onde muitos desenvolvem a confiança em si mesmos. Por isso proporciona a construção da identidade, bem como promove a inserção no meio social. O trabalhador tende a incorporar sua categoria profissional (portadora de conhecimento próprio/saber) e passa a se apresentar e atuar na sociedade como tal (MORENO, 2003).

Já que a capacidade produtiva e a produtividade passaram a ser determinantes cruciais de valor pessoal e social, a atividade laboral tornou-se uma das principais categorias de identidade e autoestima. $\mathrm{O}$ ser humano é, em grande parte, o que ele trabalha (JACOBINA, 2006). 
Atualmente, a realização profissional é sinônimo de autoestima; e identidade profissional é o mesmo que identidade pessoal. Em razão disso, o fracasso ou sucesso numa identidade implica necessariamente a outra (FREITAS, 2002).

São perceptíveis as transformações das artesãs após a inserção no Projeto Seda Justa:

Eu achei que mudou. [...] Fiquei mais saída, ah, sei lá, eu sei que fiquei mais, mais coisa, antes eu ficava só. [...] Eu aprendi a conviver mais com as pessoas. (senhora Rosa)

Não. [...] Não, sou a mesma pessoa. (senhora Margarida)

Mudou já, entrou já um dinheirinho a mais, entrou uma renda familiar que dá para melhorar a renda familiar, quando melhora, melhora as coisas em casa, com certeza, melhorou sim. [...] Eu senti que eu posso, se eu quiser posso ir mais, fazer mais e melhorar sempre. (senhora Amarílis)

[...] Ah, mudou um pouquinho, a gente se distrai mais, além do trabalho que você ganha um troquinho, é uma distração que você faz. [...] Antes eu era mais nervosa, o cachecol distrai. [...] A única coisa é que eu era mais nervosa e agora estou mais calma. (senhora Camélia)

Mudou bastante, porque eu sou bastante caseira, então antes eu quase não saía, não era muito de conversar com as pessoas e hoje não! Eu saio mais, tem mais as reuniões, converso mais com as pessoas e acabo me divertindo um pouco também, eu tava tão sozinha, então para mim foi muito importante. [...] Acho que mudou, estou um pouquinho mais importante. (senhora Jasmim)

Ah, como mudou hein, mudou bastante, mudou muito. Porque antes a minha vida era muito corrida, só dentro de casa, barracão, dentro de casa, e dependendo só do marido. [...] Eu estou aprendendo mais coisa, eu achei que na idade que eu estava, eu não ia aprender muita coisa, mas eu quero aprender muito mais do que eu estou aprendendo. [...] Ah, você se sente assim tão feliz, que coisa que antes eu não era assim, eu era uma pessoa mais nervosa, só pensava em só trabalhar. Não queria saber de sair, se eu fazia o meu serviço dentro de casa bem, e agora não. [...] Então você está ali alegre, contente. [...] Você vai crescendo, querendo aprender. (senhora Violeta)

Então, no caso, eu sou muito caseira, e eu estar mexendo com isso me obriga a deslocar da minha casa e ir à casa das outras saber as coisas. Então eu acho que isso mudou bastante. (senhora Íris)

Eu acho que não. Eu me considero a mesma coisa do que era. [...] Não noto nada, sempre igual. (senhora Acácia)

Ah, não sei. [...] Ah, eu acho que não. [...] Quer dizer, a gente aprendeu mais, foi uma coisa assim que despertou mais a curiosidade da gente de querer fazer, querer saber. [...] É, a gente aprendeu uma coisa a mais, então quer dizer que foi bom, despertou mais a gente. (senhora Clematite) 
Percebe-se que a autoconfiança das artesãs aumentou. Pelo menos é o que se pode observar das narrativas. Apenas duas delas acham que permanecem a mesma pessoa no decorrer destes três anos de projeto, observou-se um equívoco dessa forma no resgate de suas memórias. As demais salientaram que deixaram de ser apenas donas de casa, passaram a sair mais, a conversar e a conviver mais com outras pessoas e a não se sentir sozinhas.

As reuniões do projeto e as suas atividades ajudaram-lhes a se distrair, aprender novas coisas, introjetar novas práticas e modos de vida. Tornaram-nas pessoas mais curiosas, ativas, entusiasmadas. Obtiveram uma renda extra e estão aprendendo a se comportar e a falar diante das câmeras para os entrevistadores e a população em geral, o que provocou um aumento em sua autoestima.

Segundo Oliveira e Bastos (2001), o indivíduo se vê o mesmo em diferentes interações. Essa estabilidade do eu é dada por um sentido de continuidade biográfica que ele transmite aos demais. Porém, essa percepção é feita automaticamente, sem que o sujeito faça uma pré-reflexão no sentido de que se posiciona de modo diferente em diferentes momentos e lugares, de acordo com os diversos papéis que está desempenhando, em busca de sempre manter uma imagem favorável de si mesmo. Mas se ele o fizer, perceberá que transforma e constrói a si e ao mundo por meio da reflexividade.

De acordo com Strauss (1999), as mudanças nas relações com os outros são, por vezes, tão graduais que chegam a passar despercebidamente. Caso a pessoa não reflita sobre sua trajetória, é capaz de sequer notálas. Na maior parte das vezes só se dá conta quando acontece algo fortuito que revele a extensão da mudança. É por isso que o fenômeno da construção da identidade é algo que acontece sem que se perceba.

Para Moreno (2003), esse tipo de confusão ocorre pelo fato de a identidade ser definida historicamente segue um processo histórico, que possui passado, presente e futuro - e não biologicamente (as mesmas desde o nascimento até a morte), como muitos imaginam quando se referem a si mesmos. Em face disso, os indivíduos, por vezes, se percebem de maneira equivocada. Isso porque se transformam apresentando novos valores, avaliações e classificações, o que implica alterações no perceber, rememorar e valorizar da pessoa (STRAUSS, 1999).

A identidade não pode ser fixa porque as pessoas sofrem transformações a todo o momento e percebem, assim, as coisas, as pessoas e o mundo que as cercam de uma forma diferente da anterior - as identificações mudam ao longo de sua trajetória.

\section{Conclusões}

Somente através das histórias que as artesãs narraram sobre si mesmas é que foi possível extrair a essência de suas vidas. Apesar de toda a densidade de suas experiências consolidadas, pode-se vislumbrar o significado que elas atribuem ao contexto em que estão inseridas, sem a simplificação de toda a complexidade existente. O que permite atingir-se o objetivo neste artigo, que foi o de compreender de que forma a tecnologia social contribuiu para o processo de construção e constituição da identidade das artesãs da comunidade da Vila Rural Esperança.

Cada uma das artesãs entrevistadas não apenas vivenciou as transformações ocorridas de forma positiva, com muitos aspectos similares, como também vê esse processo de transformação como algo necessário à sobrevivência e manutenção de sua identidade, a qual elas próprias construíram e conquistaram por meio de muito esforço e trabalho.

Notou-se, com este estudo, que a identidade individual ou pessoal implica a noção de unicidade que caracteriza uma história de vida contínua e única de fatos sociais específicos. 
Pelos relatos das participantes da pesquisa e parceiros do projeto Seda Justa, observou-se que desde o início, no ano de 2007, o projeto possui um lado socialmente responsável, preocupado em utilizar recursos naturais e em proporcionar uma alternativa de renda às artesãs por meio do trabalho. No entanto, o projeto Seda Justa é também visualizado como um negócio por todos, uma vez que visam à obtenção de lucro por meio dele.

Em princípio, o projeto destinava-se somente aos criadores do bicho-da-seda. No entanto, isso logo mudou, antes mesmo de sua implantação na comunidade da Vila Rural Esperança, visto que poucos se interessaram.

Com a transformação de associação para cooperativa, constituiu-se a Artisans Brasil - Seda Justa Cooperativa de Artesãos de Seda de Nova Esperança (COPRASEDA). Essa mudança possibilitou a ampliação do número de produtoras rurais que hoje se dedicam a confeccionar cachecóis, desenvolver novos produtos de seda e processos de tecelagem, assim como ampliar o número de lojas da Artisans du Monde, que adquirem os produtos das artesãs, entre outros mercados.

O projeto Seda Justa é composto apenas por mulheres. O idealizador do projeto menciona que as mulheres são a base do comércio justo e reconhece o trabalho delas, oferece a elas um emprego seguro, que incrementa sua renda e permite acesso à tecnologia, o que também contribuiu para que se escolhesse este grupo de mulheres, visto que a questão de gênero é uma das principais características da identidade pessoal e possui uma grande importância nas relações interpessoais e de trabalho.

Ao contrário do que a literatura apregoa, a tecnologia social estudada é promovedora do controle, da segmentação, da hierarquização e das relações patrão-empregado. As artesãs cumprem, dentro do projeto Seda Justa, uma programação monitorada. Apesar disso, ela é incentivadora do potencial e da criatividade das artesãs, pois estes viabilizam economicamente os empreendimentos da cooperativa.

Além disso, a tecnologia inserida na comunidade trouxe transformações ao meio ambiente local, e está de acordo com a capacidade dos sujeitos. Os envolvidos buscaram uma tecnologia que fosse compatível com sua realidade e seus conhecimentos, resolvendo assim os seus problemas. O reconhecimento de suas capacidades e suas especificidades foi considerado como prioritário na hora de implementar a tecnologia social; daí o êxito alcançado.

Quanto às características da tecnologia social, percebeu-se, pelas afirmações das artesãs, que realizam um trabalho genuinamente manual, no qual prevalece a troca de conhecimento entre os atores envolvidos nos processos. As artesãs procuram conciliar a confecção de cachecóis com os serviços domésticos, onde imperam o aprendizado, a atividade em grupo, a afinidade pelas atividades desempenhadas e a criatividade.

Confirmou-se que as artesãs desempenham tarefas simples - cada uma à sua maneira -, de baixo custo, fácil aplicabilidade e impacto social. Diariamente elas conciliam a confecção de cachecóis com os serviços domésticos. No entanto, estes são prioritários para elas - trabalham somente após o seu cumprimento. Procuram a todo o momento harmonizar os papéis de artesã, dona de casa, mãe e esposa.

As artesãs identificam-se com o seu trabalho, e este faz sentido para elas, pois, por meio dele, sentem-se mais úteis e ativas, além de introjetarem novas práticas e estilos de vida. Assim, conseguem desempenhar o papel que assumiram no ambiente de trabalho e atender às expectativas de seu grupo social, construindo e reconstruindo, desta forma, a sua identidade pessoal, por meio do trabalho e de suas colegas de trabalho.

As artesãs construíram e constituíram suas identidades por meio do trabalho. Ele é fonte de renda e, também, de muita satisfação, visto que preenche o tempo livre que possuem, gostam das tarefas desempenhadas, e por ser um elo que as liga com pessoas de dentro e de fora do projeto. Com o advento da cooperativa Artisans Brasil - Seda Justa (COPRASEDA), as artesãs almejam o seu desenvolvimento e crescimento. Enfatizam positivamente a grande diversidade de produtos e mercados que a cooperativa terá. 
Dessa forma, a tecnologia social contribuiu para o processo de construção e constituição da identidade das artesãs da comunidade da Vila Rural Esperança, por intermédio do significado do trabalho artesanal como fonte de autoestima, autorrealização e geração de renda.

A autoconfiança das artesãs aumentou, conforme observado nos relatos. Apresentaram uma grande motivação interna. Sua autoestima emergiu com o projeto Seda Justa devido ao reconhecimento dos outros, o que as levou a se orgulharem de si mesmas e a se valorizarem. As tarefas desenvolvidas (incorporação da inovação) estão estabelecendo vínculos sociais e lhes proporcionando poder econômico. O trabalho é visualizado não apenas como recurso financeiro, mas também como satisfação ou realização profissional.

O trabalho é uma referência importante para o sujeito, é um espaço onde muitos desenvolvem a confiança em si mesmos. Desse modo, proporciona a construção e constituição da identidade, bem como promove a inserção no meio social. Isso porque a capacidade produtiva e a produtividade passaram a ser determinantes cruciais de valor pessoal e social; a atividade de trabalho tornou-se uma das principais categorias de identidade e autoestima, uma vez que o ser humano é, em grande parte, o que ele trabalha.

As artesãs incorporaram o discurso do outro, uma vez que este passou a fazer parte do seu dia a dia e a conduzir suas ações. Assim, estão alienadas, pois o outro está a todo momento impondo significados sobre elas e exigindo um padrão de comportamento e pensamento que, sem perceber, adotam.

De acordo com a literatura estudada, o reconhecimento dos outros é um dos elementos fundamentais na construção da identidade da pessoa, que ocorre de modo dinâmico, mediante suas interações sociais.

A maioria das artesãs percebeu seu processo de transformação, pois pensaram em seu processo histórico e não em sua composição biológica, e assim alcançaram uma compreensão profunda de si, sem equívocos. Elas foram sensíveis o bastante para perceberem as transformações graduais pelas quais passaram ao longo de suas interações sociais e ambientes sociais. Ao fazerem um resgate de sua trajetória, conseguiram perceber como se transformaram no que são e a forma como foram construídas e constituídas, por meio dos papéis sociais que incorporaram e das experiências que vivenciaram.

Em virtude de a identidade permear sempre a igualdade e a diferença, a pessoa se identifica com grupos semelhantes a ela e, assim, acaba por diferenciar-se dos demais grupos. Em face disso, foram notados conflitos internos e externos com relação ao grupo das artesãs. Algumas são vistas como mais dedicadas e rápidas do que outras, o que demonstra uma diferenciação entre elas (membros do grupo). Percebeu-se que não há totalidade de grupo; nem todas que participam do projeto Seda Justa são tratadas como iguais.

As artesãs sentem-se como parte do grupo, possuem o sentimento de pertencer e encontram-se "psicologicamente" entrelaçadas com o destino do grupo, o que atribui, dessa forma, sentido às suas vidas.

A filiação a um grupo de prestígio afeta a autoestima da pessoa, visto que ela toma para si as experiências de sucesso e fracasso do grupo. A imagem que a pessoa tem de si encontra-se ligada àquela que tem de seu grupo - os que não se encontram inseridos nele são diferenciados e excluídos.

As artesãs sentem-se prestigiadas por pertencer ao projeto Seda Justa e por exportar suas confecções - o reconhecimento nacional veio como consequência do reconhecimento internacional. O contato com o meio externo à Vila Rural Esperança surgiu com a comercialização dos produtos para a França, por meio do sistema de comércio justo. As filmagens são percebidas por elas como um lado positivo do trabalho, por serem reconhecidas pessoalmente e profissionalmente por outras pessoas.

As artesãs estão conseguindo atribuir significados e sentidos ao seu trabalho, por meio da ação e das relações sociais que estão estabelecendo, o que contribui para a formação e objetivação de suas identidades. 
Apesar de esta pesquisa ter cumprido os objetivos a que se propôs, não foi possível captar toda a realidade, visto que foi realizado apenas um recorte dela. Assim, sabe-se que possui algumas limitações. A sugestão, aqui, é que sejam realizados estudos futuros com artesãs de outros lugares, para que novas singularidades de vida sejam encontradas.

Vale ressaltar que o presente trabalho nos remete à importância da multidisciplinaridade nas ciências administrativas, pois nos leva a refletir sobre as práticas contemporâneas de gestão de recursos humanos no que diz respeito a relações de trabalho, seus dilemas e significados.

\section{Referências}

ALVESSON, Mats; BILLING, Yvonne Due. Understanding gender and organizations. London: Sage, 1997.

ARTISANS BRASIL - SEDA JUSTA. Disponível em: <http://www.artisansbrasil.com>. Acesso em: 17 jun. 2009.

ASHFORTH, Blake E., MAEL, Fred. Social Identity Theory and the Organization. Academy of Management Review, v. 14, n. 1, p. 20-39, 1989.

BAUER, Márcio André Leal. A construção social da identidade: um estudo nas organizações de agricultura ecológica em duas regiões do RS. 2004. Dissertação (Mestrado em Administração) - Programa de Pós-Graduação em Administração da Universidade Federal do Rio Grande do Sul, Porto Alegre, 2004.

BAUMAN, Zygmunt. Identidade: entrevista a Benedetto Vecchi. Trad. Carlos Alberto Medeiros. Rio de Janeiro: Zahar, 2005.

BERGER, Peter L., LUCKMANN, Thomas. A construção social da realidade: tratado de sociologia do conhecimento. Trad. Floriano de Souza Fernandes. 6. ed. Petrópolis: Vozes, 1985.

BILANCIERI, Marcos Vinício; PADOVEZE, Clóvis Luis. Políticas Públicas para geração de emprego e renda: Avaliação do Proger urbano e sua contribuição para a gestão empresarial através de um estudo no município de Pederneiras. In: ANPAD - EnAPG: ENCONTRO DE ADMINISTRAÇÃO PÚBLICA E GOVERNANÇA. 5., 2006. São Paulo. Anais... São Paulo, 2006. 1 CD-ROM.

CASTELLS, Manuel. A era da informação: economia, sociedade e cultura. O poder da identidade. 2.ed. São Paulo: Paz e Terra, 2000. [Volume II].

CIAMPA, Antônio da Costa. A estória do Severino e a história da Severina: um ensaio de psicologia social. São Paulo: Brasiliense, 1996.

DAGNINO, Renato Peixoto. Tecnologia social é inédita e revolucionária. Disponível em: <http: www.rts.org.br/noticias/forum_RTS/tecnologia-social-e-inedita-e-revolucionaria>. Acesso em: 26 out. 2008.

DAGNINO, Renato Peixoto; BRANDÃO, Flávio Cruvinel; NOVAES, Henrique Tahan. Sobre o marco analíticoconceitual da tecnologia social. In: LASSANCE JR. et al., (Org.). Tecnologia social: uma estratégia para o desenvolvimento. Rio de Janeiro: Fundação Banco do Brasil, 2004.

DUBAR, Claude. A socialização: construção das identidades sociais e profissionais. Porto: Porto, 1997.

ELIAS, Norbert. A sociedade dos indivíduos. Organizado por Michael Schröter. Rio de Janeiro: Jorge Zahar Editor Ltda., 1994.

ERIKSON, Erik H. Identidade: juventude e crise. Rio de Janeiro: Guanabara, 1976.

FERNANDES, Claudia Sousa. Representações e construção da identidade do professor de inglês. 2006. Dissertação (Mestrado) - Pontifícia Universidade Católica de São Paulo, Programa de Pós-Graduação em Linguística Aplicada e Estudos da Linguagem, 2006. 
FREITAS, Maria Ester de. Cultura organizacional: identidade, sedução e carisma. Rio de Janeiro: FGV, 2002. p. 83101.

GADAMER, Hans Georg. Verdade e método. Trad. Flávio Paulo Meurer. Petrópolis, RJ: Vozes, 1997.

GIDDENS, Anthony. Modernidade e identidade. Trad. Plínio Dentzien. Rio de Janeiro: Jorge Zahar Editor, 2002.

HALBWACHS, Maurice. A memória coletiva. Trad. Laís Teles Benoir. São Paulo: Centauro, 2004.

HALL, Stuart. A identidade cultural na pós-modernidade. Rio de Janeiro: DP\&A, 2005.

. Quem precisa de identidade? In: SILVA, Tomaz Tadeu da. (Org.). Identidade e diferença: a perspectiva dos estudos culturais. 7. ed. Petrópolis, RJ: Vozes, 2007.

JACOBINA, Olga Maria Pimentel. Adolescente em conflito com a lei: trabalho e família. 2006. Dissertação (Mestrado) - Programa de Pós-Graduação em Psicologia Clínica, Universidade de Brasília, Brasília, 2006.

LASSANCE JÚNIOR, Antonio Ernesto Albuquerque; PEDREIRA, Juçara Santiago. Tecnologias sociais e políticas públicas. In: LASSANCE JR. et al. (Org.). Tecnologia social: uma estratégia para o desenvolvimento. Rio de Janeiro: Fundação Banco do Brasil, 2004.

LOPES, Luiz Paulo da Moita. Práticas narrativas como espaço de construção das identidades sociais: uma abordagem socioconstrucionista. In: RIBEIRO, Branca Telles; LIMA, Cristina Costa; DANTAS, Maria Tereza Lopes. (Orgs.). Narrativa, identidade e clínica. Rio de Janeiro: Edições IPUB - CUCA, 2001. p. 55-71.

MAHEIRIE, Kátia. Identidade: o processo de exclusão/inclusão na ambiguidade dos movimentos sociais. In: ZANELLA, Andréa V et al. (Orgs.). Psicologia e práticas sociais. 19. ed. Porto Alegre: ABRAPSOSUL, 1997.

MARIGA, Jandira Turatto. Desenvolvimento, implementação e avaliação de um programa de aprendizagem ambiental para condomínios residenciais: enfoque em resíduos sólidos, Dissertação (Mestrado em Engenharia de Produção) - Programa de Pós-Graduação em Engenharia de Produção, Universidade Federal de Santa Catarina, Florianópolis, 2004.

MEAD, George H. Mind, self and society: from a standpoint of a social behaviorist. Chicago/London: The University of Chicago Press, 1972. p. 135- 226.

MENDES, Luciano; ICHIKAWA, E. Y. O desenvolvimento tecnológico e o pequeno produtor rural: construção, desconstrução ou manutenção da sua identidade? In: ENANPAD - ENCONTRO ANUAL DA ASSOCIAÇÃO NACIONAL DE PÓS-GRADUAÇÃO E PESQUISA EM ADMINISTRAÇÃO. 31., 2007, Rio de Janeiro. Anais... Rio de Janeiro: ANPAD, 2007. 1 CD-ROM.

MOLON, Susana Inês. O processo de exclusão/inclusão na constituição do sujeito. In: ZANELLA, Andréa V. et al. (Orgs.). Psicologia e práticas sociais. 19 ed., Porto Alegre: ABRAPSOSUL, 1997. p. 19-28.

MORENO, Bruno Stramandinoli. 2003. Identidade e trabalho: um panorama sobre globalização. Monografia (Especialização) - Programa de Pós-Graduação em Psicologia Organizacional e do Trabalho, Universidade Estadual de Londrina, 2003.

NEDER, Ricardo Toledo. Tecnologia social como pluralismo tecnológico. In: ESOCIT JORNADAS LATINOAMERICANAS DE ESTUDOS SOCIAIS DAS CIÊNCIAS E DAS TECNOLOGIAS. 7., 2008 , Rio de Janeiro. Anais... Rio de Janeiro, 2008.

NUNAN, Adriana. Homossexualidade: do preconceito aos padrões de consumo. Rio de Janeiro: Caravansarai, 2003. p. 116-136.

OLIVEIRA, Ailton Souza de. Autonomia vigiada: caminhos para a construção da identidade profissional dos docentes do colégio militar de Campo Grande - MS. 2007. Dissertação (Mestrado em Educação) - Programa de Pós-Graduação em Educação, Universidade Católica Dom Bosco, Campo Grande, 2007. 
OLIVEIRA, Maria do Carmo Leite de; BASTOS, Liliana Cabral. Saúde, doença e burocracia: pessoas e dramas no atendimento de um seguro saúde. In: RIBEIRO, Branca Telles; LIMA, Cristina Costa; DANTAS, Maria Tereza Lopes. (Orgs.). Narrativa, identidade e clínica. Rio de Janeiro: Edições IPUB - CUCA, 2001. p. 162-189.

OTERO, Martina Rillo; JARDIM, Fabiana Alves. Reflexões sobre a construção do conceito de tecnologia social. In: LASSANCE JR. et al., (Org.). Tecnologia social: uma estratégia para o desenvolvimento. Rio de Janeiro: Fundação Banco do Brasil, 2004.

PEREIRA, Bill Nunes; TEIXEIRA, Eduardo André; OJIMA, Ayrosa, Sayuri. Consumo entre gays: compreendendo a construção da identidade homossexual através do consumo. In: ENANPAD - ENCONTRO ANUAL DA ASSOCIAÇÃO NACIONAL DE PÓS-GRADUAÇÃO E PESQUISA EM ADMINISTRAÇÃO. 29., 2005 , São Paulo. Anais... Rio de Janeiro: ANPAD, 2005. 1 CD-ROM.

REDE DE TECNOLOGIA SOCIAL (RTS). Documento Constitutivo - Propósito. Disponível em: <http://www.rts.org.br/a-rts/proposito>. Acesso em: 26 out. 2008.

Registro do $1^{\text {o }}$ Fórum Nacional da RTS em Salvador, Bahia/ Brasil de 5 a 8 de dezembro de 2006. Anais eletrônico... Organizadora Rede de Tecnologia Social, Brasília: Editora Abipti, 2006. Disponível em: <http://www.rts.org.br/noticias/destaque-2/arquivos/16abr2007_rts_anais_final.pdf. Acesso em: 26 out. 2008.

RUTKOWSKI, Jacqueline; LIANZA, Sidney. Sustentabilidade de empreendimentos solidários: que papel espera-se da tecnologia? In: LASSANCE JR et al. (Org.). Tecnologia social: uma estratégia para o desenvolvimento. Rio de Janeiro: Fundação Banco do Brasil, 2004.

SILVA, Tomaz Tadeu da. A produção social da identidade e da diferença. In: SILVA, Tomaz Tadeu da (Org.). Identidade e diferença: a perspectiva dos Estudos Culturais. 7. ed. Petrópolis, RJ: Vozes, 2007.

SOMERS, Margaret R.; GIBSON, Gloria D. Reclaiming the Epistemological "other": narrative and the social constitution of identity. In: CALHOUN, Craig. (Ed.) Social theory and the politics of identity. Cambridge: Blackwell, 1995. p. 37-99.

STRAUSS, Anselm L. Espelhos e Máscaras: a busca de identidade. Trad. Geraldo Gerson de Souza. São Paulo: EDUSP, 1999.

TABAK, Fanny. O laboratório de Pandora: estudos sobre ciência no feminino. Rio de Janeiro: Garamond, 2002. $262 \mathrm{p}$.

TRIVIÑOS, Augusto Nibaldo Silva. Introdução à pesquisa em ciências sociais: a pesquisa qualitativa em educação. São Paulo: Atlas, 1987.

VALA, Jorge. Representações sociais e psicologia social do conhecimento quotidiano. In: VALA, Jorge; MONTEIRO, Maria Benedicta (Coord.). Psicologia social. 6. ed. Edição da Fundação Calouste Gulbenkian, 2004. p. 457-502.

VELHO, Gilberto. Projeto e metamorfose: antropologia das sociedades complexas. Rio de Janeiro: Jorge Zahar Editor, 1994.

VIEIRA, Marcelo Milano Falcão. Por uma boa pesquisa (qualitativa) em administração. In: VIEIRA, Marcelo Milano Falcão; ZOUAIN, Deborah Moraes (Orgs.). Pesquisa qualitativa em administração. Rio de Janeiro: FGV Editora, 2004.

VOTRE, Sebastião Josué. Linguagem, identidade, representação e imaginação. In: FERREIRA, Lucia M. A.; ORRICO, Evelyn G. D. (Orgs.). Linguagem, identidade e memória social: novas fronteiras, novas articulações. Rio de Janeiro: DP\&A, 2002. 